\title{
Introduksi Pangan Lokal pada Produk Olahan Ikan sebagai Upaya Peningkatan Daya Saing
}

\author{
Yohana Sutiknyawati Kusuma Dewi ${ }^{1}$, Oke Anandika Lestari², \\ Widadi Padmarsari ${ }^{3}$ \\ 1,2,3 Universitas Tanjungpura
}

\begin{abstract}
Article History ABSTRACT
Received 12.09.2019

Received in revised form

05.11.2019

Accepted 02.12.2019

Available online 16.12.2019

LOCAL FOOD INTRODUCTIONS INTO FISH PROCESSED PRODUCT AS A

WAY TO ENHANCE COMPETITIVE VALUE. Bilayuk Village is one of $18.25 \%$ underdeveloped village with IDM (Village Development Index) score below 0.491. Based on Forum Group Discussion results with village officials, one of the main reasons is the village's human resources lack of knowledge. The lack of human resources knowledge leads to unutilised village's local food. The abundant and unutilised local foods are tubers and san-sankng leaves. The tuber has potential as filling agent to reduce the amount of fish use in fish processed product, and san-sankq leaves can be used as flavour enhancer substitute (MSG). Therefore, in this community service activity, we provide training and assistance to fish cultivators in Bilayuk village to process the harvest into hekeng which enriched with tubers filling and used san-sankq leaves for seasoning. The purpose of the activity is to increase local competitive value of Bilayuk village with increasing knowledge in fish processing by processed it into hekeng made from local food. The results showed that there is increasing knowledge since audience never made hekeng and processing food without flavour enhancer before, $77 \%$ target audience understand how to make hekeng, $22 \%$ target audience really like the result, and the rest of the audience just like the result. All audience are practising how to make hekeng for their family consumption. The audience are expected to have interest to make hekeng to increase their family income.
\end{abstract}

KEYWORDS: Bilayuk, Hekeng, San-Sakng, Sweet Potato. and reproduction in any medium, provided the original work is properly cited. ○) 2019 Mochamad Mochklas, Achmad Hariri.

\section{PENDAHULUAN}

Jumlah desa sangat tertinggal di Indonesia berdasarkan nilai Indeks Desa Membangun (IDM) adalah 13.453 Desa atau 18,25\%. Kalimantan Barat memiliki persentase Indeks Desa Membangun (IDM) dengan katagori desa sangat tertinggal tertinggi yaitu 49,9\% dibandingkan provinsi Kalimantan lainnya. Salah satu desa yang

${ }^{2}$ Corresponding author: Program Studi Ilmu dan Teknologi Pangan, Faperta Universitas Tanjungpura Pontianak; Jl. Prof. Dr. H. Hadari. Nawawi, Pontianak, Kalimantan Barat. Email: oke.anandika@gmail.com 
memiliki IDM dibawah 0,491 (sangat tertinggal) adalah Desa Bilayuk dengan nilai IDM 0,4773 (Hamidi et al., 2015). Berdasarkan hal tersebut maka desa Bilayuk menjadi salah satu sasaran pembangunan. Kegiatan ini juga mendukung program pemerintah untuk mencapai Rencana Pembangunan Pembangunan Jangka Menengah Nasional 2015-2019 (RPJMN 2015-2019) yaitu menurunkan jumlah desa tertinggal hingga 5000 desa dan meningkatkan desa mandiri paling sedikit 2000 pada tahun 2019.

Hasil Focus Group Discussion (FGD) dengan perangkat Desa Bilayuk diketahui bahwa salah satu penyebab rendahnya nilai IDM adalah dari indikator pendidikan. Melimpahnya sumber daya alam belum didukung dengan pengetahuan masyarakat. Terdapat sekelompok budidaya ikan yang menjadi fokus desa Bilayuk. Kelompok tersebut telah memiliki 32 kolam yang berisikan ikan nila dan ikan mas. Ikan yang dihasilkan tersebut hanya digunakan untuk pemenuhan keperluan keluarga atau dijual dengan tetangga. Kendala yang dihadapi adalah kurangnya pengetahuan untuk mengolah ikan sehingga ikan hanya diolah secara sederhana seperti di goreng, sehingga mengurangi minat anak untuk mengkonsumsi ikan. Oleh sebab itu dalam kegiatan ini bertujuan meningkatkan pengetahuan dalam mengolah ikan yang diperkaya dengan bahan lokal.

Pengayaan produk olahan ikan dengan bahan pangan lokal seperti umbi salah satu tujuannya adalah untuk menekan biaya produksi. Umbi pada posisi hal tersebut umumnya dikatakan sebagai bahan pengisi atau bahan yang menggantikan penggunaan ikan. Penggunaan umbi dengan berbagai konsentrasi sebagai bahan pengisi pada produk olahan ikan atau sejenisnya telah banyak diteliti, yaitu konsentrasi $10 \%$ pada pembuatan nugget daging sapi (Astriani, Kusrahayu, \& Mulyani, 2013), dan 30\% pada pembuatan nugget ikan madidihang (Thalib, 2011). Kegiatan ini akan mengaplikasikan pangan lokal ubi jalar dengan konsentrasi 30\% sebagai bahan pengisi pada pembuatan hekeng ikan mas. Pemilihan ubi jalar sebagai bahan pengisi karena bahan tersebut banyak ditanam oleh masyarakat desa Bilayuk, sedangkan jenis produk olahan hekeng dipilih karena produk tersebut salah satu produk khas Kalimantan Barat akan tetapi masyarakat Bilayuk belum pernah membuatnya, sehingga dapat menambah pengetahuan dalam mengolah ikan.

Micin atau monosodium glutamat (MSG) merupakan bahan tambahan makanan yang umum digunakan dimasyarakat, akan tetapi keberdaannya secara alami di bahan pangan belum banyak diketahui. MSG merupakan bentuk garam natrium dari asam glutamat yang termasuk asam amino non esensial dan banyak terkandung pada buah, sayur, dan daging (Saraswati \& Hardinsyah, 2012). Bahan alami yang sudah diteliti mengandung MSG secara alami adalah daun san-sakng. Asam glutamat bebas dalam daun san-sakng segar sebesar $40,44 \mathrm{mg} / \mathrm{g}$ b.k (Mayasari, 2016). Bentuknya yang bebas dalam bahan pangan menentukan rasa lezat. Hal tersebut seperti yang disebutkan Setiawati dan Sri (2008), makanan yang mengandung glutamat bebeas dalam jumlah besar biasanya memberikan rasa yang lezat. Glutamat dapat memberikan rasa umami atau gurih bila ditambahkan pada makanan yang asin, seperti menurut Mayasari, Lestari, Saloko, dan Ulfa (2017) penggunaan daun san-sakng dengan 0,6\% garam pada jenis makanan asin memiliki tingkat kesukaan yang paling tinggi. Daun ini umumnya telah digunakan oleh masyarakat etnis dayak di Kalimantan Barat sebagai bumbu masakan. Oleh sebab itu dalam kegiatan ini hekeng diperkaya dengan bahan lokal tersebut. 


\section{METODE PELAKSANAAN}

Kegiatan pengabdian kepada masyarakat dilakukan di Desa Bilayuk Kabupaten Landak Provinsi Kalimantan Barat. Khalayak sasaran adalah kelompok budidaya ikan dan kader posyandu yang berjumlah 25 orang yang mayoritas adalah ibu-ibu. Target pada kegiatan ini adalah meningkatkan pengetahuan pembudidaya ikan untuk mengolah ikan terutama ditingkat keluarga sehingga meningkatkan minat untuk konsumsi ikan.

Metode yang digunakan adalah dengan sosialisasi, pelatihan, serta evaluasi dan monitoring. Sosialisasi memuat materi pengolahan ikan menjadi hekeng dan pengambilan data awal sebelum kegiatan. Pelatihan berisikan demonstrasi dan pelatihan pengolahan hekeng yang juga dilakukan praktek pengulangan oleh khalayak sasaran. Evaluasi dan monitoring berupa pengambilan data setelah kegiatan untuk mengukur keberhasilan kegiatan. Pengambilan data dilakukan dengan memberikan kuisoner pada khalayak sasaran. Analisis data dilakukan secara deskriptif dengan mengkalkulasi menjadi bentuk persen.

\section{HASIL DAN PEMBAHASAN}

Kegiatan awal yang dilakukan adalah sosialisasi (Gambar 1). Kegiatan tersebut diisi dengan memberikan edukasi terkait pengolahan ikan menjadi produk hekeng dengan menggunakan ubi jalar sebagai bahan pengisi dan daun san-sakng sebagai pengganti micin. Kegiatan ini juga dilakukan pengambilan data awal untuk melihat ada tidaknya peningkatan pengetahuan dari hasil kegiatan. Informasi yang diperoleh sebanyak $88,9 \%$ khalayak sasaran menggunakan micin pada setiap masakan dan 100\% khalayak sasaran tidak mengetahui bahan alami yang dapat menggantikan micin. Berdasarkan hal tersebut dapat dikatakan bahwa kegiatan ini tepat sasaran dan dapat menambah pengetahuan khalayak sasaran.

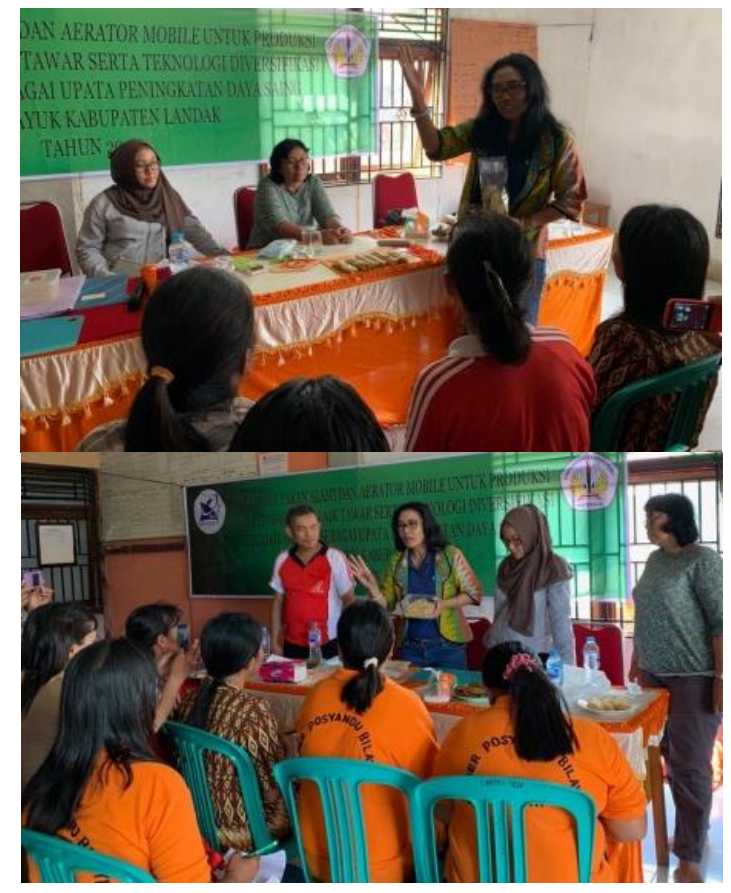

Gambar 1. Kegiatan Sosialisasi 
Kegiatan selanjutnya adalah pelatihan pembuatan hekeng yang dilengkapi dengan pemberian brosur yang berisi langkah-langkah pembuatan hekeng (Gambar 2). Bahan baku ikan yang digunakan adalah ikan mas yang merupakan jenis ikan yang sedang di budidayakan oleh Kelompok Budidaya ikan di Desa Bilayuk. Pembuatan hekeng dengan ikan mas menggunakan bahan pengisi ubi jalar kukus sebanyak $30 \%$.

Pelatihan pada kegiatan ini dilakukan dengan cara perwakilan khalayak sasaran mengulang proses pengolahan hekeng yang telah didemonstrasikan. Khalayak sasaran terlihat trampil dan dapat mengulang proses pengolahan hekeng dengan baik. Hal tersebut didukung dengan data kuisioner (Gambar 3) yang menunjukkan bahwa khalayak sasaran sebanyak $11 \%$ sangat faham dan $67 \%$ faham terhadap materi pengolahan hekeng yang diberikan. Bedasarkan hal tersebut dapat dikatakan bahwa 78\% khalayak sasaran dapat menerima materi pelatihan dengan baik.

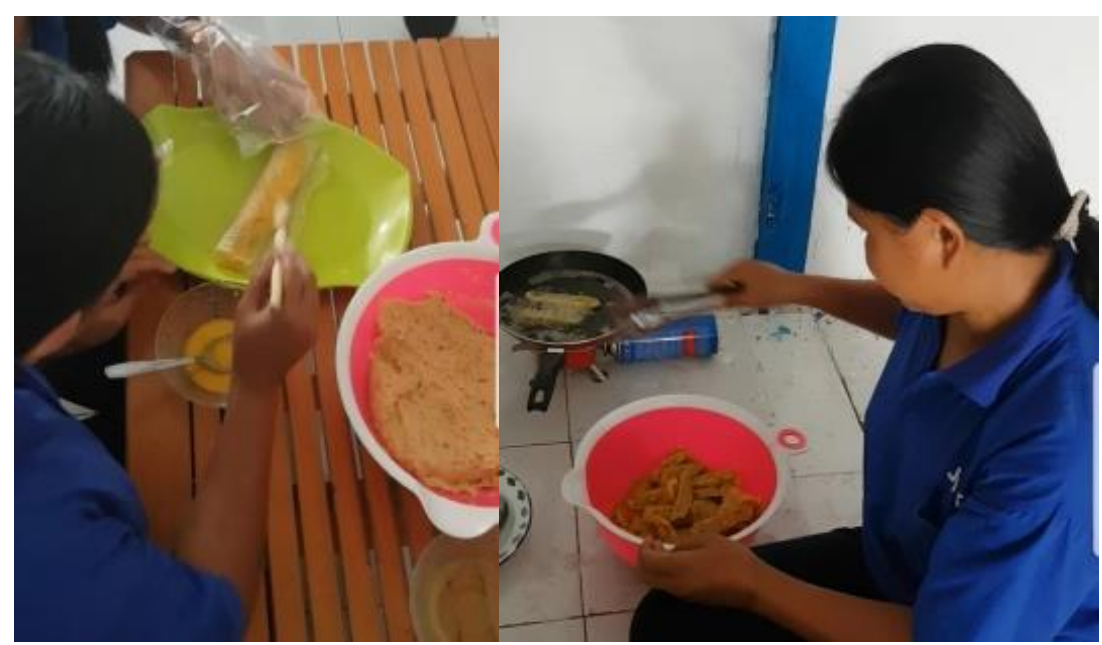

Gambar 2. Kegiatan Pelatihan

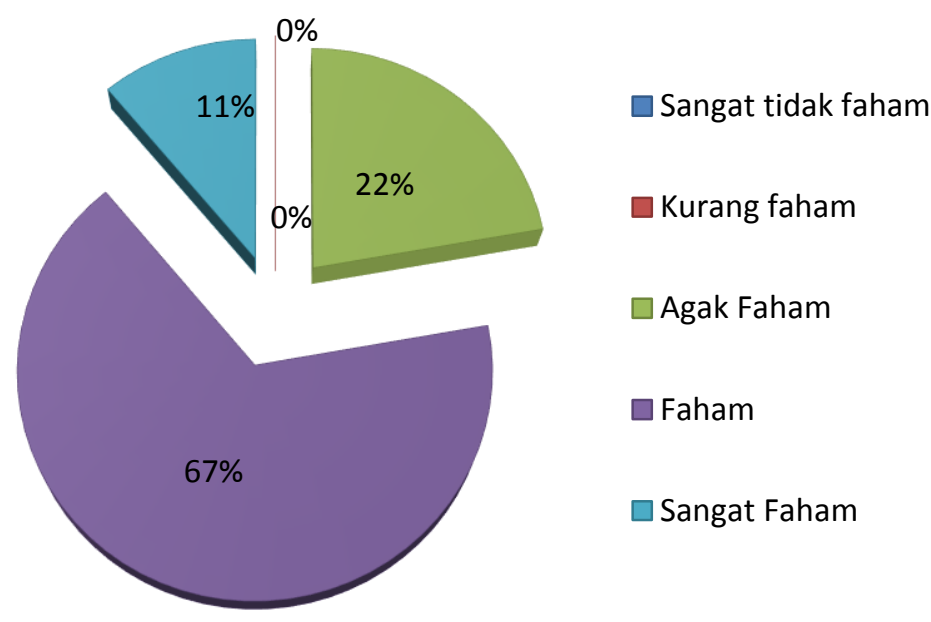

Gambar 3. Grafik Persentase Tingkat Pemahaman Khalayak Sasaran terhadap Materi Pelatihan 


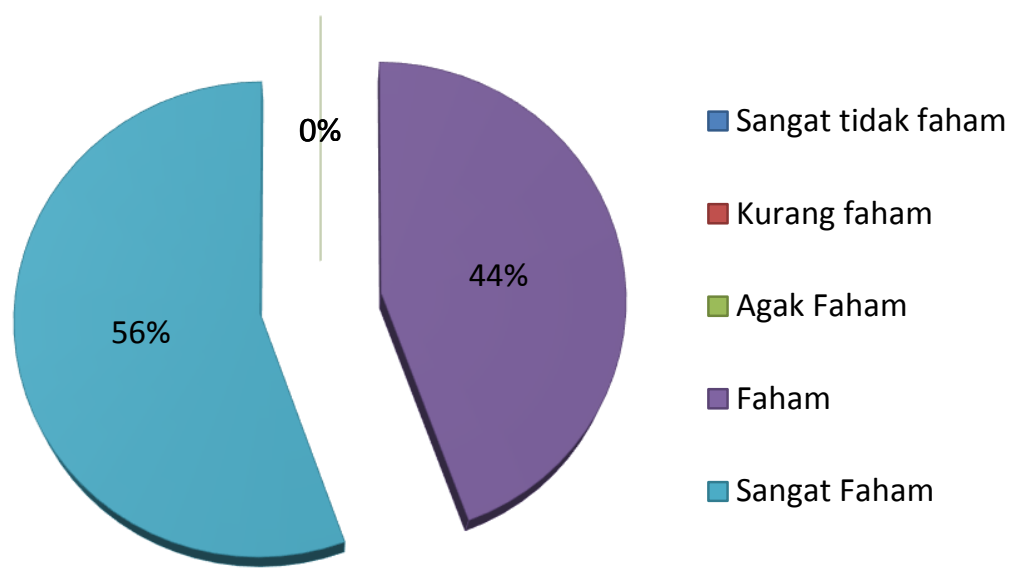

Gambar 4. Grafik Persentase Tingkat Pemahaman Khalayak Sasaran Terhadap Brosur Materi Pelatihan

Kegiatan pelatihan pengolahan hekeng didukung dengan penggunaan brosur. Tingkat pemahaman terhadap brosur yang diberikan ditampilkan pada Gambar 4. Hasil menunjukkan bahwa khalayak sasaran sebanyak $46 \%$ sangat faham dan $44 \%$ faham terhadap brosur yang diberikan. Hasil tersebut menunjukkan bahwa penggunaan brosur dapat mendukung atau melengkapi terkait materi pelatihan pengolahan hekeng. Hal tersebut juga dijelaskan pada hasil penelitian Atmaja (2014), bahwa penggunaan panduan dapat meningkatkan pemahaman terhadap materi yang diberikan. Panduan yang diberikan pada kegiatan ini adalah berupa brosur.

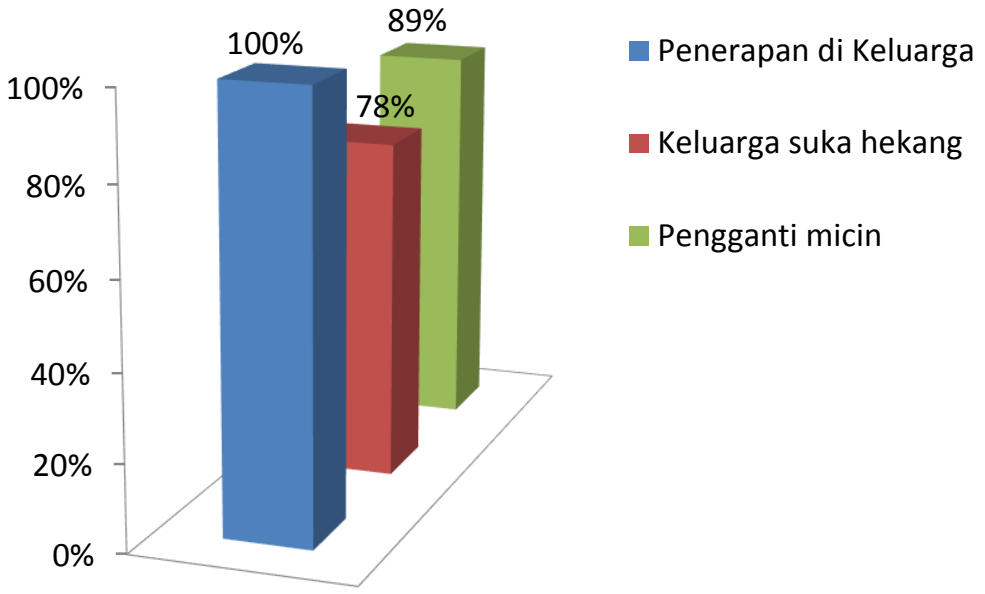

Gambar 5. Grafik Persentase Tingkat Khalayak Sasaran yang Menjawab Ya

Kegiatan evaluasi dan monitoring dilakukan pengambilan data terkait penerapan dan peningkatan pengetahuan sebagai indikator utama keberhasilan kegiatan ini. Hasil tersebut digambarkan pada Gambar 5. Keberhasilan kegiatan ditunjukkan dengan seluruh khalayak sasaran membuat hekeng untuk disajikan kepada keluarga dengan jumlah keluarga khalayak sasaran sebanyak $78 \%$ suka terhadap hekang yang dihasilkan. 
Hal tersebut sesuai dengan hasil Sokib, Palupi, dan Suharjo (2012), bahwa minat konsumsi ikan dapat ditingkatkan dengan dikembangkan menjadi produk olahan seperti nugget. Persamaan juga dilaporkan oleh Lestari, Dewi, dan Hadari (2018), pengolahan ikan nilai menjadi produk olahan nugget dan kornet meningkatkan kesukaan dalam mengkonsumsi ikan. Berdasarkan hasil kegiatan ini peningkatan konsumsi ikan juga memungkinkan dilakukan dengan pengolahan ikan menjadi hekeng. Peningkatan pengetahuan ditunjukkan dengan sebanyak $89 \%$ khalayak sasaran dapat menjawab bahan alami yang dapat menggantikan micin, dimana jawabannya adalah gula dan daun san-sakng.

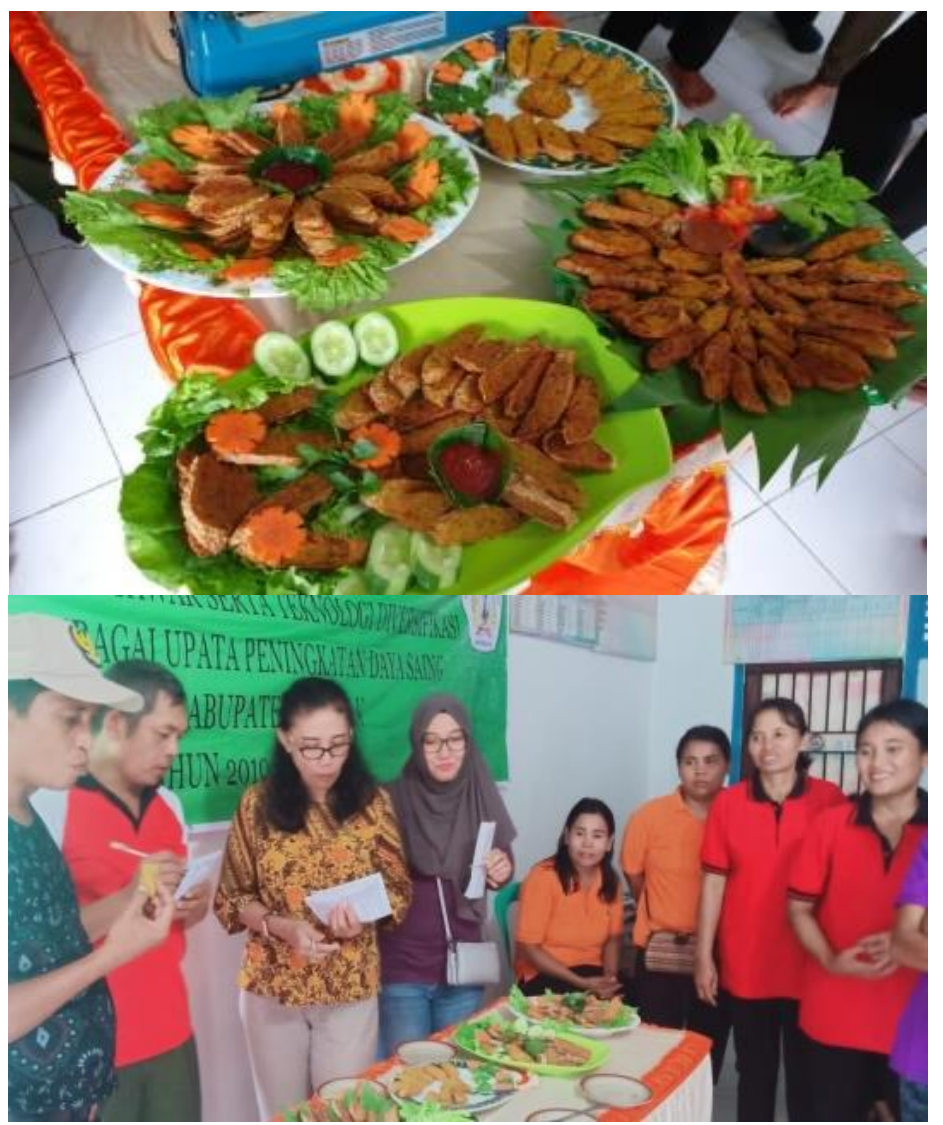

Gambar 5. Hasil Pengembangan Resep Hekeng oleh Khalayak Sasaran

Peningkatan pengetahuan pengolahan juga ditunjukkan dengan khalayak sasaran mampu mengolah hekang dengan bahan baku lain (Gambar 6). Bahan baku lain yang digunakan diantaranya adalah ikan nila dan udang. Produk yang dihasilkan juga menunjukkan hasil yang baik dan sesuai dengan yang didemonstrasikan.

\section{SIMPULAN}

Peningkatan pengetahuan pengolahan ikan menjadi hekeng yang diperkaya produk lokal yaitu ubu jalar dan pengganti micin terlihat padaseluruh khalayak sasaran telah menerapkan pengolahan hekeng di tingkat keluarga dan $89 \%$ khalayak sasaran dapat menjawab bahan alami yang dapat menggantikan micin. Salah satu keberhasilan kegiatan dapat diukur bahwa 78\% keluarga suka terhadap hekeng yang dihasilkan. 
Saran atau harapan untuk keberlanjutan kegiatan ini adalah perangkat desa dapat memfasilitasi dan memotifasi khalayak sasaran untuk mengembangkan produk hekeng menjadi produk unggulan desa dan dipasarkan.

\section{UCAPAN TERIMA KASIH}

Penulis sampaikan banyak terimakasih kepada Direktur Riset dan Pengabdian Masyarakat Direktorat Jenderal Penguatan Riset dan Pengembangan Kementerian Riset, Teknologi, dan Pendidikan Tinggi yang telah mendanai kegiatan ini melalui Program Prototipe Teknologi untuk Masyarakat dengan nomor perjanjian 177/SP2H/PPM/DRPM/2019. Ucapan terima kasih juga diberikan kepada Bapak Lipinus beserta tim yang telah mendukung keberlangsungannya kegiatan ini.

\section{REFERENSI}

Atmaja, T. T. (2014). Upaya meningkatkan perencanaan karir siswa melalui bimbingan karir dengan penggunaan media modul. Psikopedagogia, 3(2), 58-68.

Astriani, R. P., Kusrahayu, K., \& Mulyani, S. (2013). Pengaruh berbagai filler (bahan pengisi) terhadap sifat organoleptik beef nugget. Animal Agriculture Journal, 2(1), 247252.

Hamidi, H., Setijonegoro, F. X. N., Fujitriartanto., Sa'id, A., Harioso., Huda., Hardiyanto, A., Waluyanto, B., Lubis, I. S. G., Setiawan, D., Prayitno, H., \& Mu'arofah, A. F. (2015). Indeks Desa Membangun. Jakarta: Kementerian Desa, Pembangunan Daerah Tertinggal dan Transmigrasi.

Lestari, O. A., Dewi, Y. S., \& Hadari, Y. (2018). Pangan setengah jadi berbasis ikan sebagai salah satu alternatif penurunan angka stunting dan peningkatan angka kecukupan protein (akp) tingkat rumah tangga. Sakai Sambayan Jurnal Pengabdian kepada Masyarakat, 2(3), 94-98.

Mayasari, E. (2016). Pengaruh variasi suhu kyuring terhadap komposisi asam glutamat bebas pada daun sokai (Albertisia papuana becc). In H. J. Tjahjono, R. Isdius (Eds.), Hilirisasi sumber daya alam Kalimantan Barat untuk meningkatkan daya saing produk pangan dan kosmetika. Paper presented at Seminar Nasional Hasil Riset Baristand Industri Pontianak, Hotel Mercure Pontianak, 8 September 2016 (pp. 72-78). Pontianak: Balai Riset dan Standarisasi Industri Pontianak.

Mayasari, E., Lestari, O. A., Saloko, S., \& Ulfa, M. (2017). Karakteristik sensori ekstrak daun san-sakng (Albertisia papuana becc.) dengan penambahan $\mathrm{NaCl}$ diberbagai konsentrasi pada panelis semi terlatih. Jurnal Ilmiah Teknosains, 3(1), 27-33.

Saraswati, M. M. D., \& Hardinsyah. (2012). Pengetahuan dan perilaku konsumsi mahasiswa putra tingkat persiapan bersama ipb tentang monosodium glutamat dan keamanannya. Jurnal Gizi dan Pangan, 7(2), 111-118. 
Setiawati, F. S. N., \& Sri, N. (2008). Dampak penggunaan monosodium glutamat (MSG) terhadap kesehatan lingkungan. Semarang: FT UNDIP.

Sokib, N., Palupi, N. S., \& Suharjo, B. (2012). Strategi peningkatan konsumsi ikan di Kota Depok, Jawa Barat. MANAJEMEN IKM: Jurnal Manajemen Pengembangan Industri Kecil Menengah, 7(2), 166-171.

Thalib, A. (2011). Uji tingkat kesukaan nugget ikan madidihang (Thunnus albacares) dengan bahan pengisi yang berbeda. Agrikan: Jurnal Agribisnis Perikanan, 4(1), 58-64. 